\title{
Serum amyloid A concentrations during the course of acute ischaemic heart disease
}

\author{
RUTH SHAINKIN-KESTENBAUM,* Y WINIKOFF, ${ }^{*}$ N CRISTAL $\dagger$ \\ From the Departments of ${ }^{*}$ Nephrology and $\dagger$ Coronary Service, Soroka University Hospital, Faculty of \\ Health Sciences, Ben-Gurion University of the Negev, Beer-Sheva, Israel
}

SUMMARY Serum amyloid A concentrations were determined in serial serum samples of 41 patients with confirmed acute myocardial infarction (10 with acute ischaemia and two with myocarditis). A sharp increase in serum amyloid A concentration was observed early at onset of infarct; it peaked on the third day (up to 2200 fold of normal values) and declined towards normal during the following days, if no complications occurred. Different patterns were observed in patients with acute ischaemia or myocarditis.

Although serum amyloid $A$ is not a specific marker, it may, because of its high sensitivity and characteristic patterns of change, represent an additional useful biochemical variable in the diagnosis, follow up, and prognosis of acute ischaemic heart disease.

Ischaemic necrosis of the myocardium is a powerful stimulus for activation of the acute phase reaction. This observation has been fully appreciated since the early days when fever, leucocytosis, and increased erythrocyte sedimentation rate were the usual indicators of acute reaction. The rise in fibrinogen after myocardial infarction is a well known phenomenon, ${ }^{1-3}$ as well as rises in $\mathrm{C}$ reactive protein ${ }^{45}$ and $\alpha_{1}$-antitrypsin. ${ }^{6}$ Serum amyloid $\mathrm{A}$, an apolipoprotein of High density lipoproteins, is one of the most sensitive acute phase reactants. ${ }^{7}$ Its serum concentration increases greatly in response to tissue damage, malignancy, and bacterial or viral disease. ${ }^{8-11}$ It has been suggested that amyloid $A$, the main fibrillar protein deposit in secondary amyloidosis, is derived from serum amyloid $A$ by proteolytic cleavage. ${ }^{12-14}$ The biological function of serum amyloid $A$ is not known; in vitro studies, however, suggest that it may be responsible for the suppression of immune response. $^{15}$

The aim of the present study was to evaluate the behaviour of serum amyloid A concentrations in early and late phases of acute myocardial infarction and acute ischaemia to find out if it can serve as a biochemical indicator in cases in which the known laboratory markers suit neither the clinical situation nor the patient's symptoms.

Accepted for publication 23 January 1986

\section{Material and methods}

Fifty three patients who were admitted to the coronary unit were included in the study. Fifty of these were men, and the mean (SD) age was 59.9(11.2) years. Forty one patients developed acute myocardial infarction (diagnosed by the presence of at least two of the following three criteria: typical history; development of new $Q$ waves in the electrocardiogram; and a typical rise in the enzyme creatine-P-kinase, glutamate oxaloacetate transaminase and lactic dehydrogenase. Creatine-P-kinase was tested in only 19 of the patients). Of the remaining 12 patients, acute myocardial ischaemia was diagnosed in $\mathbf{1 0}$ and myocarditis (probably of viral aetiology) in two. The ischaemic patients included those with chest pain, ST$P$ changes in electrocardiogram without development of $Q$ waves, and those without an increase of serum enzyme activity.

Blood samples were taken on admission and subsequently on the second, third, fourth, sixth and tenth days. Serum amyloid A concentrations were determined by radioimmunoassay, as previously described $^{910}$ and expressed as amyloid $A$ equivalents. Normal range for our laboratory is $0.5-2 \mu \mathrm{g} \mathrm{ml}^{-1}$. Creatine-P-kinase activities were measured by the ultraviolet method of Boehringer Mannheim diagnostica, normal range at $37^{\circ} \mathrm{C}$ being $24-195$ units $1^{-1}$. Plasma fibrinogen concentrations were determined by the nephelometric technique, normal range being $200-400 \mathrm{mg} \%$. 


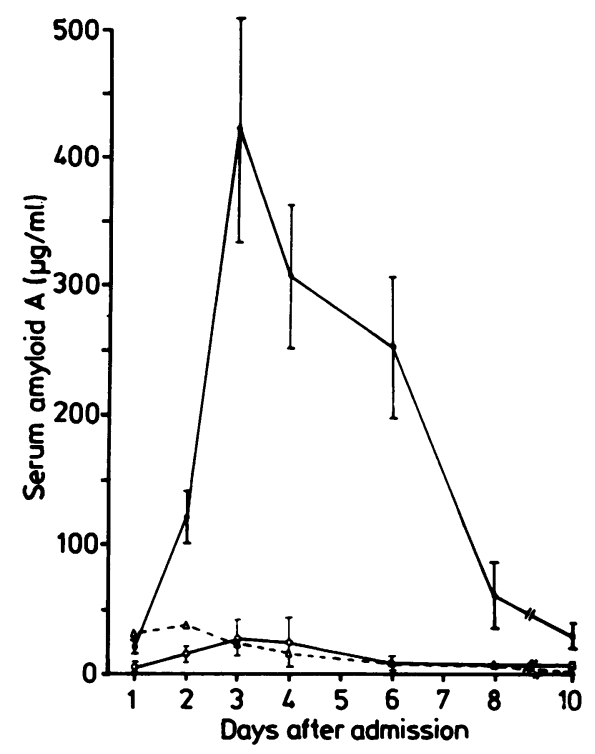

Fig. 1 Ten day follow up of serum amyloid $A$ concentrations in patients with acute myocardial infarction (-) ; acute ischaemia $(\mathrm{O}-\mathrm{O})$, and myocarditis $(\Delta \cdots \Delta)$. Each date point is the mean (SE) except in the two patients with myocarditis.

\section{Results}

Fig. 1 shows the changes in serum amyloid A concentrations during the course of 10 days in 41 patients with acute myocardial infarction, 10 patients with acute ischaemia, and two patients with myocarditis. The rise in serum amyloid A concentrations was more pronounced in patients with acute myocardial infarction than in the two other groups. In patients with acute myocardial infarction concentrations of serum amyloid A were above normal $\left(19.9 \mu \mathrm{g} \mathrm{ml}^{-1}\right.$ (SE 4.6)), with a range of $2.4 \mu \mathrm{g} \mathrm{ml}^{-1}$ to $96 \mu \mathrm{g} \mathrm{ml}^{-1}$

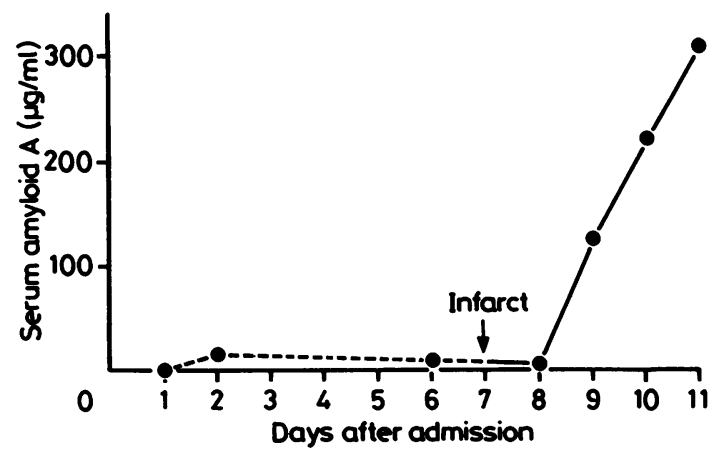

Fig. 2 Course of serum amyloid A concentrations in a patient admitted with acute ischaemia who developed infarction on the seventh day (arrow). Broken lines indicate ischaemia, full lines myocardial infarction.

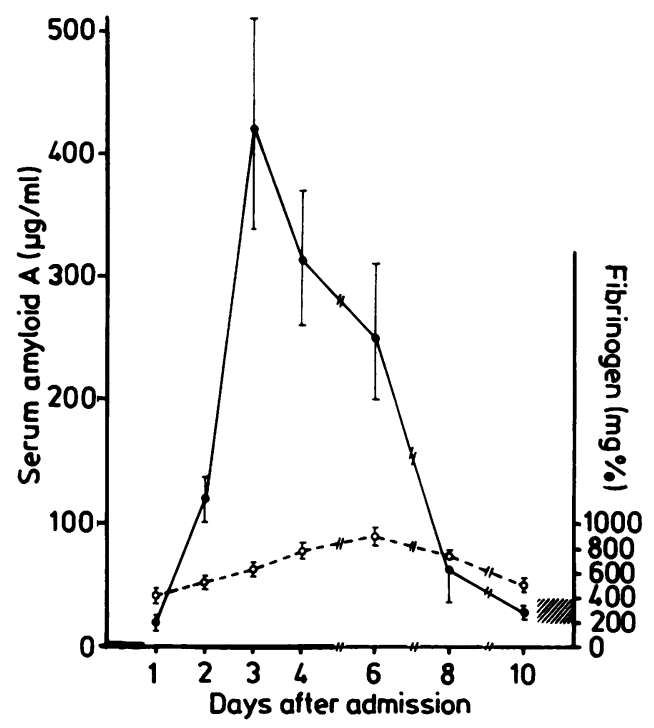

Fig. 3 Behaviour of serum amyloid $A$ and fibrinogen concentrations in patients with acute myocardial infarction.

even on the first day after the onset of symptoms, and they increased sharply to maximal values on the third day, $422(84.7) \mu \mathrm{g} \mathrm{ml}^{-1}$, maximum $2200 \mu \mathrm{g} \mathrm{ml}^{-1}$. On the tenth day the values were still above normal ( 30 (7.8) $\mu \mathrm{g} \mathrm{ml}^{-1}$, range $1.5-76.5 \mu \mathrm{g} \mathrm{ml}^{-1}$ ). In patients with ischaemia the maximum mean value was also $\stackrel{\mathbb{Q}}{\AA}$ reached on the third day, was $27(14.6) \mu \mathrm{g} \mathrm{ml}^{-1}$, the $\overrightarrow{\vec{F}}$ maximum being $61 \mu \mathrm{g} \mathrm{ml}^{-1}$. A small rise in serum $\frac{\circ}{3}$ amyloid A concentrations was also observed in the two patients with myocarditis on the first and second days after admission.

Serum amyloid $\mathbf{A}$ and creatine-P-kinase values? were compared in a group of 19 patients with $\frac{3}{3}$ confirmed acute myocardial infarction who were admitted to the coronary unit. Serum amyloid A con- $\bigcirc$ centrations correlated significantly with creatine-Pkinase $(r=0.632 ; p<0.05)$ in a group of 13 patients who were admitted six to 24 hours after onset of $>$ symptoms. In six patients who were admitted less than 36 hours after onset of infarct only serum amyloid AN concentrations were high, while creatine-P-kinase activities were already within the normal range.

Fig. 2 describes serum amyloid A concentrations in $\omega$ a patient admitted with acute ischaemia. There was a moderate increase in serum amyloid A concentrationce up to the seventh day, when an infarction developed $\mathbb{\Phi}$ and a typical sharp increase in serum amyloid $A$ was? detected.

Fig. 3 shows the behaviour of serum amyloid $A$ and $\stackrel{\vec{P}}{\vec{P}}$ fibrinogen in acute myocardial infarction. While the mean serum amyloid A concentrations rose by more $\stackrel{\mathbb{\Omega}}{\Omega}$ than $\mathbf{4 0 0}$ times normal levels in myocardial infarctiono by the third day, the fibrinogen peak occurred later (on the sixth day) and was only two to three timeso higher than normal. A positive correlation was 
Peak serum amyloid A concentrations and complications: congestive heart failure, cardiac arrest, and pericarditis in 41 patients with acute myocardial infarction*

\begin{tabular}{llll}
\hline & \multicolumn{3}{c}{ Serum amyloid A values $\left(\mu \mathrm{g} / \mathrm{ml}^{-1}\right)$} \\
\cline { 2 - 4 } & $<300$ & $300-1000$ & $>1000$ \\
\hline $\begin{array}{l}\text { No of patients } \\
\begin{array}{l}\text { No (\% of patients } \\
\text { with complications) }\end{array}\end{array}$ & 21 & 15 & 5 \\
\hline
\end{tabular}

*The patients were divided into three groups according to their peak serum amyloid A values.

detected in acute myocardial infarction between peak values of these two values: $r=0.36 ; p<0.05$.

In an attempt to evaluate the correlation of the clinical course of acute myocardial infarction with serum amyloid A concentrations 41 patients were divided into three groups according to their maximal serum amyloid $A$ value (Table). The following complications were recorded: congestive heart failure, cardiac arrest, and pericarditis. Of the patients with peak serum amyloid A values up to $300 \mu \mathrm{g} / \mathrm{ml}$, only $48 \%$ developed one or more of these complications. Of those with maximal values between $300-1000 \mu \mathrm{g} / \mathrm{ml}$, $60 \%$ developed complications, and $80 \%$ of the patients with peak values higher than $1000 \mu \mathrm{g} / \mathrm{ml}$ showed one or more of these complications.

\section{Discussion}

Myocardial necrosis is a powerful stimulant for acute phase response. A two to three fold rise in plasma fibrinogen concentrations, ${ }^{1-3}$ increased concentrations of $\alpha_{1}$-antitrypsin, ${ }^{6}$ as well as a rise in $C$ reactive protein activities, ${ }^{45}$ were found after acute myocardial infarction. It has been suggested ${ }^{5}$ that monitoring $\mathrm{C}$ reactive protein activities may assist in the early recognition of complications after myocardial infarction. Our study shows a very early rise in serum amyloid $A$ values from the first hours to more than $\mathbf{2 0 0 0}$ fold on the third day after acute infarction.

When comparing the concentrations of serum amyloid $\mathbf{A}$ after myocardial infarction and those reported after other diseases, such as myocarditis, viral, ${ }^{1011}$ and other infections, ${ }^{8}$ it is evident that tissue injury in the myocardium is a more potent stimulant for serum amyloid A production than damage to other tissues.

In a previous report ${ }^{17}$ we showed the high sensitivity of fibrinogen concentrations for predicting abnormal uptake of technetium $99 \mathrm{~m}$ pyrophosphate. The present study reopens the question as to whether follow up of the serum amyloid A, or other acute phase reactant protein values, may provide an earlier and more sensitive indicator of the presence of myocardial necrosis. Although the acute phase response is a non-specific manifestation of tissue injury, its precise quantification can provide a valuable aid to the clinician at the bedside. Although our study did not clearly define the relation between serum amyloid $\mathrm{A}$ concentrations and prognosis, we were impressed by the potential diagnostic value of the early rise in serum amyloid $A$. This early rise may be helpful in the diagnosis of myocardial necrosis in patients in whom typical ischaemic pains are not followed by enzymatic changes or development of $Q$ waves or when reinfarction or extension of the necrosis is suspected.

This work was supported by a grant from the Israeli Academy of Science Basic Research.

\section{References}

${ }^{1}$ Fulton RM, Duckett K. Plasma fibrinogen and thromboembolism after myocardial infarction. Lancet 1976;ii:1161-4.

${ }^{2}$ Gidron E, Magelit R, Oliver A, Shalitin Y. Effects of myocardial infarction on components of fibrinolytic system. Br Heart J 1977;39:19-25.

${ }^{3}$ Cristal N, Slonim A, Bar-Ilan I, Hart A. Plasma fibrinogen levels and the clinical course of acute myocardial infarction. Angiology 1983;34:693-8.

${ }^{4}$ Kushner I, Broder ML, Karp D. Control of the acute phase response. Serum C-reactive protein kinetics after acute myocardial infarction. $J$ Clin Invest 1978;61:235-42.

${ }^{5}$ De Beer FC, Hind CRK, Fox KM, Allan RM, Maseri A, Pepys MB. Measurement of serum C-reactive protein concentration in myocardial ischaemia and infarction. Br Heart $J$ 1982;47: 239-43.

${ }^{6}$ Gilutz HJ, Siegel I, Paran E, Cristal N, Quastel M. Alpha $_{1}$-antitrypsin in acute myocardial infarction. $\mathrm{Br}$ Heart $J$ 1983;49:4926-30.

${ }^{7}$ Benditt EP, Erickson N. Amyloid protein SAA is associated with high density lipoprotein from human serum. Proc Natl Acad Sci USA 1977;74:4025-8.

${ }^{8}$ Rosenthal CJ, Franklin EC. Variation with age and disease of an amyloid A protein-related serum component. J Clin Invest 1975;55:746-53.

${ }^{9}$ Rosenthal CJ, Sullivan L. Serum amyloid A to monitor cancer dissemination. Ann Intern Med 1979;91:383-90.

${ }^{10}$ Sarov I, Shainkin-Kestenbaum R, Zimlichman S, Winikoff Y, Chaimovitz C. Serum Amyloid A levels in patients with infections due to cytomegalovirus, varicella-Zoster virus and herpes simplex virus. J Infect Dis 1982;146:443.

${ }^{11}$ Shainkin-Kestenbaum R, Zimlichman S, Winikoff Y, Pras M, Chaimovitz C, Sarov I. Serum Amyloid A (SAA) in viral infection: rubella, measles and subacute sclerosing panencephalitis (SSPE). Clin Exp Immunol 1982;50:503-6.

${ }^{12}$ Levin M, Pras M, Franklin EC. Immunologic studies of the major non-immunoglobulin protein of amyloid. I. Identification and partial characterization of a related serum component. $J$ Exp Med 1973;138:373-80.

${ }^{13}$ Husby G, Natvig JB. A serum component related to nonimmunoglobulin amyloid protein as a possible precursor of the fibrils. J Clin Invest 1974;53:1054-61.

${ }^{14}$ Lavi G, Zucker-Franklin D, Franklin EC. Elastase type proteases of the surface of human blood monocytes: a possible role in amyloid formation. J Immunol 1980;125:175-9.

${ }^{15}$ Benson MD, Aldo-Benson M. Effect of purified protein SAA on immune response in vitro: mechanisms of suppression. $J$ Immunol 1979;122:2077-82.

Requests for reprints to: Dr $\mathbf{R}$ Shainkin-Kestenbaum, Nephrology Department, Soroka Medical Centre, BeerSheva 84101 , Israel. 